\title{
Between Self Congruity, Destination Relationship and Memorable Tourist Experience: an Empirical Study on Destination Loyalty
}

\author{
Elia Ardyan $\bowtie$, Utomo Wibisono
}

Management Departement, Sekolah Tinggi Ilmu Ekonomi Surakarta, Sukoharjo, Indonesia

\begin{tabular}{l} 
Info Article \\
\hline History Article: \\
Received 28 December 2018 \\
Approved 9 August 2019 \\
Published March 2019 \\
\hline Keywords: \\
Memorable Tourist Experience; \\
Destination Personality; Self-Con- \\
gruity; Destination Relationship; \\
Destination Loyalty
\end{tabular}
Received 28 December 2018 Approved 9 August 2019 Published March 2019

Memorable Tourist Experience; Destination Loyalty

\begin{abstract}
This study examines the driving factors that can enhance tourist destination loyalty. Respondents used were 184 domestic tourists who had traveled to Bali. Data were analyzed using Structural Equation Modeling. Amos version 21 is used to process data. These results indicate that destination personality can improve the relationship destination but memorable tourist experience can not enhance it. The personality of a tourist destination enhance self-congruity. The study also found that memorable tourist experiences and the relationship destinations has a positive impact on increasing destinations loyalty. Selfcongruity has a negative effect on destination loyalty. One contribution of this research related to showing the memorable tourist experience is more likely to influence loyal decisions than destination relationships.
\end{abstract}

\section{Antara Kesesuaian Diri, Hubungan Destinasi, dan Pengalaman Turis yang Mengesankan: Studi Empiris pada Loyalitas Destinasi Wisata}

\begin{abstract}
Abstrak
Studi ini menguji faktor-faktor pendorong yang mampu meningkatkan loyalitas destinasi wisata. Responden di dalam penelitian ini adalah 184 turis domestik yang pernah berwisata ke Bali. Data dianalisis dengan menggunakan Structural Equation Modeling. Amos versi 21 digunakan untuk mengolah data. Hasil penelitian ini menunjukkan bahwa personalitas destinasi wisata mampu meningkatkan hubungan destinasi wisata namun pegalaman turis yang mengesankan tidak mampu meningkatkannya. Personalitas destinasi wisata juga mampu meningkatkan kesesuaian diri. Penelitian ini juga menemukan bahwa pengalaman turis yang mengesankan dan hubungan destinasi wisata memberikan dampak positif pada peningkatan loyalitas turis domestik untuk loyal pada destinasi wisata. Kesesuaian diri sebagai salah satu pendorong loyalitas terbukti berpengaruh negatif pada loyalitas destinasi wisata. Salah satu kontribusi dari penelitian ini terkait dengan menunjukkan pengalaman wisata yang berkesan lebih mungkin untuk mempengaruhi keputusan yang loyal daripada destination relationship.
\end{abstract}

JEL Classification: M31,M39

How to Cite: Ardyan, E., \& Wibisono, U. (2019). Between Self Congruity, Destination Relationship and Memorable Tourist Experience: an Empirical Study on Destination Loyalty. Jurnal Dinamika Manajemen, 10(1), 111-123. 


\section{INTRODUCTION}

Tourism provides an important role in the economy (Li et al., 2018; Mariani \& Baggio, 2012) in a country. The positive impact of tourism includes creating jobs, improving infrastructure (Abubakirova et al., 2016), increasing business around tourist sites, and several other positive impacts. In terms of marketing, tourist destinations have an impact on visitor behavior (Hosany et al., 2006; Usakli \& Baloglu, 2011), satisfaction, consumer trust (Chen \& Phou, 2013), self-congruence (Klipfel et al., 2014) and loyalty (Kumar et al., 2006). In order to increase tourist visits, tourist destinations must compete with each other to make their destination the best (Mariani \& Baggio, 2012). Destination marketers have long recognized the importance of promoting and building their brand goals in the minds of tourists (Chen \& Phou, 2013). Management and development of tourist destinations must be carried out effectively (Pearce \& Schanzel, 2013) so that tourist destinations have competitive advantages. Destination managers must be able to attract potential tourists so that they are satisfied (Enright \& Newton, 2004; Gursoy et al., 2014). A well-managed destination will have an impact on increasing tourists and loyalty.

Tourist destination loyalty is an important part of tourist management (Oppermann, 2000). Some researchers explain the importance of destination loyalty (Elmeida-Santana \& Moreno-Gil, 2017; Tasci, 2017; Almeida-Santana \& Moreno-Gil, 2018; Al-Ansi \& Han, 2019; Alrawadieh et al., 2019; Cossio-Silva et al., 2019; Fu, 2019). Loyalty can predict post visit behavior (Chen \& Chen, 2010) and become a sustainable competitive advantage for the company (Sun et al., 2013; Gursoy et al., 2014). Refer to the concept of loyalty from Oliver (1999), destination loyalty consists of traveler behavior and attitudinal. Traveler behavior consists of various real actions of tourists related to destination revisit or willingness to revisit a destination. The attitudinal traveler is associated with a positive attitude towards tourists, followed by giving positive recommendations to others. Destination loyalty dimensions are divided into three parts, namely providing positive recommendations, willingness to revisit, and destination revisit (Jani \& Han, 2012). Some studies focus on discussing tourist destination loyalty (Alegre \& Juaneda, 2006; Chi \& Qu, 2008; Sun et al., 2013). The indication of loyal tourists having the intention to visit again and tell positive things about the tourist destination (Chi \& $\mathrm{Qu}, 2008)$. The loyalty of tourist destinations as loyalty that does not depend on conditions, condition-dependent loyalty (high or low session) and recommend to other parties (Meleddu et al., 2015).

Tourist activities that stay at hotels in Bali can indicate enthusiastic tourists to visit the island of Bali. Data from the Central Statistics Agency (2019) shows a decrease in the average stay activity of tourists. In general, there was a decrease in almost types of star-rated hotels from 2013 to 2018 . There was a decrease in visitors at 1 -star hotels by $15.63 \%, 2$-star hotels by $28.13 \%$, 3-star hotels by 34.73\%, 4-star hotels by $19.71 \%$, while 5-star hotels increased by $33 \%$. These problems must be overcome immediately by increasing promotions and various stimuli so that tourists want to visit the island of Bali.

Research conducted by Sudiarta and Suardana (2016) ocuses on domestic tourists. About 12 tourist sites in Bali that were in great demand by tourists. The location was chosen because it is very attractive for tourists. An interesting destination indication is the fulfillment of several aspects, such as: infrastructure, facilities (Mill \& Morrison, 2009), amenity, access, (Cooper et al., 1993), quality of education, cultural facilities (Ardyan \& Susanti, 2018), etc. Tourist destinations must also be able to offer an unforgettable experience to tourists. These things will be able to increase tourist visits and loyalty

Many studies focus on tourist destinations on the island of Bali (McTaggart, 1980; Gibbons \& Fish, 1989; Cole, 2012; Mariani \& Baggio, 2012; Sutawa, 2012; Law et al., 2016; Sudiarta \& Suardana, 2016). Many experts re- 
search Bali island because this tourist destination is exciting. The focus of this research is local tourists who have visited tourist destinations on the island of Bali. We want to analyze several essential factors that influence the loyalty of local tourists. First, self-congruence. Some researchers focus on the concept of self-congruence on tourism (Chon, 1992a; Litvin \& Goh, 2002; Litvin \& Kar, 2003; Kastenholz, 2004; Boksberger et al., 2011). Developing congruity for target markets allows marketers to choose product image attributes (self, ideal, and social), which creates the highest level of congruity (Johar \& Sirgy, 1989). Second, destination relationship. Destination relationship is related to the brand relationship concept. This concept addresses the relationship between visitors and tourist destinations. The third is memorable customer experience. Creating a memorable tourist experience is an essential part of the hospitality industry (Pizam, 2010; Tung \& Ritchie, 2011). The tourism industry aims to facilitate extraordinary experiences (Walls et al., 2011), looking for fantasy, feeling, and pleasure (Holbrook \& Hirschman, 1982), and seeing tourism as the peak consumers (Wang, 2002).

This study examines the driving factors that can increase tourist destination loyalty. The driving factor that we analyze is a memorable tourist experience, self-congruity, and destination relationship. This research uses structural equation modeling analysis. One contribution of this research related to showing the memorable tourist experience is more likely to influence loyal decisions than destination relationships.

\section{Hypothesis Development \\ Relationship between Personality Destina- tions and Relationship Destination}

Destination personality is an essential part of a powerful brand (Aaker, 1996; Morgan \& Pritchard, 2010). The concept of tourist destination personality refers to the concept of brand personality. Brand personality influences brand relationship quality (Tho et al., 2016). The personality of tourist destinations as a set of human characteristics attached to tourism ob- jects (Hosany et al., 2006). Tourist locations are strived to be more different in increasingly competitive markets; destination personalities can build destination brands, understand tourist perceptions about tourist attractions, and develop the unique personality of tourist destinations (Caprara et al., 2001). The concept of tourist destination personalities is measured by the following indicators: sincerity, excitement, competence, sophistication, and rudeness. Destination personality can influence preference and choice behavior (Murphy et al., 2007). Destination personality is also able to influence the emotional connection between tourists and place (Park \& Jung, 2010). The quality of relationships is divided into three dimensions, namely, satisfaction, trust, and attachment (Fournier, 1998). In this study, the relationship of tourist destinations in this study was explained by three dimensions, namely satisfaction, trust, and attachment to tourist destinations. Tourist destination personalities could enhance the dimensions of relations with tourist destinations (satisfaction and trust) (Chen \& Phou, 2013). Based on this explanation, we propose the following hypothesis:

$\mathrm{H1}$ : The destination personality has a positive effect on relationship destination

\section{Relationship between Destination Persona- lity and Self Congruity}

Marketers try to attach a set of human characteristics to a particular brand. This concept is called a personality brand (Aaker, 1997). Perceptions of human personality characteristics are inferred from individual beliefs, attitudes and demographic characteristics (Park et al., 1986), whereas perceptions of brand personality traits can be influenced and shaped by direct or indirect interactions with brands (Plummer, 2000). The Brand Personality Scale often measures the concept of brand personality, and many are replicated by various researchers both for objects that form products or services (Aaker, 1997). Brand personality can influence user imagery, where user imagery is a picture of the brand image transferred to brands from individuals 
considered as typical users of brands (Klipfel et al., 2014). Brand personality is also able to influence consumer choice towards a particular brand (Plummer, 1985; 2000). Consumers will be delighted if they buy and consume a brand that matches the image they want. Consumers also like that they are different from other consumers. They need a brand that can do it. The concept of self-congruence is the compatibility/ incompatibility between the perception of the destination image and the tourist's self-image (Ahn et al., 2013). The self-congruity theory extensively studies the influence of self-congruence and brand personality (Klipfel et al., 2014). Other research shows that the personality of tourist destinations has a positive impact on self congruity (Sirgy \& Su, 2000; Usakli \& Baloglu, 2011). They can fulfill their self-consistency and self-esteem after the use and ownership of certain brands that share the same personality with them. Based on this explanation, we propose the following hypothesis:

$\mathrm{H} 2$ : Destination personality has a positive impact on self-congruity.

\section{Relationship between Self-Congruity and Destination Loyalty}

Self-congruence is the conformity/incompatibility between the perception of the destination image and the tourist's self-image (Ahn et al., 2013). Consumers buy products or brands that they believe have the same symbol images and complement their self-image (Health \& Scott, 1998). The self-congruence theory postulates that symbolic characteristics cause high brand preference. Symbolic characteristics will strengthen and validate individual self-perceptions (Swann et al., 1992). Self-congruence can predict consumer behavior (Hosany \& Martin, 2012). Destination self-congruence affects visiting intention, recommending intention, positive attitudes, destination satisfaction, and tourist loyalty (Chon, 1992a; Sirgy \& Su, 2000; Litvin \& Goh, 2002; Beerli et al., 2007; Kwak $\&$ Kang, 2009). Self congruity has a significant influence on buying behavior ( $\mathrm{Ha} \& \mathrm{Im}, 2012$ ). Other research results show that self congruity has a positive impact on first-time entrants and tourists who have come many times (Liu et al., 2012a).

Han and Back (2008) focus on one type of self congruence, which is the ideal of social image congruence, where this type can influence consumer loyalty. Kang et al. (2015) found that self congruity has a positive impact on loyalty. A consumer will show supportive and beneficial feelings for a brand when the brand personality is in accordance with their self-image (Park \& Lee, 2005). This will cause consumers to prefer brands whose image or personality matches their self-image (Kotler \& Keller, 2012). Products or services that are in accordance with self-image, someone will be satisfied and loyal to these products and services. Based on this explanation, the third hypothesis can be formulated as follows :

H3: Self-Congruity has a positive impact on destination loyalty

\section{Relationship between Memorable Tourist Experience, Destination Relationship, and Destination loyalty}

Experience can be concluded as the total perception and customer response related to the learning process when dealing directly or indirectly with the product or company. The overall amount of consumer perception created during the learning process(Carbon dan Heckel, 1994). Consumer experience as an internal and subjective response where consumers have a relationship either directly or indirectly with the company (Rageh et al., 2013). The experience of tourism as a relationship between people, and the amount of their world view depends on their central location to the community in which they are located (Cohen, 1979). A memorable tourist experience is also defined as a tourism experience that is easy to remember even though the event has been going on for a long time (Sthapit, 2013). Consumer experience will improve the quality of relationships between consumers and brands (Fournier, 1998). Previous studies explain the strong relationship between brands and consumers due to strong emotional bon- 
ding factors (Pawle \& Cooper, 2006), which is obtained through memorable experiences. The fourth hypothesis can be argued as follows:

$\mathrm{H} 4$ : Memorable tourist experience has a positive effect on destination relationship

The concept of a Brand relationship explains that a brand has a particular relationship with its customers. The more consumers have a relationship with the brand (the more they love a particular brand), the more they can have an impact on brand loyalty (Batra et al., 2012). The brand relationship dimension was able to increase brand loyalty significantly (Veloutsou , 2015). Some researchers explain that brand relationship quality is the best predictor of brand loyalty intention (Kressmann et al., 2006; Hollebeek, 2011). Based on this explanation, we propose the following hypothesis:

H5: Destination relationship has a positive effect on destination loyalty

The study of consumer experience has increased to be phenomenal (Schmitt, 1999a, 1999b; Prahalad \& Ramaswamy, 2004; Ponsonby-Mccabe \& Boyle, 2006). Creating a memorable experience has become a priority for various companies. Therefore, companies must create a design to create experiences that are attractive to consumers and able to be remembered by customers (Pine \& Gilmore, 1998). Marketers must design innovative experiences to improve the core competencies of companies engaged in tourism and hospitality (William, 2006). Canadian Tourism Commission (2004) investigate how a country can create a memorable experience to engage tourists and increase customer loyalty sufficiently. Consumers who have experience with products, brands, shopping and others will influence loyalty (Brakus et al., 2009; Biedenbach \& Marrel, 2010; Ismail et al., 2011; Sahin et al., 2011; Sathish \& Venkatesakumar, 2011). Therefore, the hypothesis regarding the memorable tourist experience can be formulated as follows:

H6: Memorable tourist experience has a positive effect on destination loyalty
From the explanation above, we propose the empirical research model as shown in Figure 1:

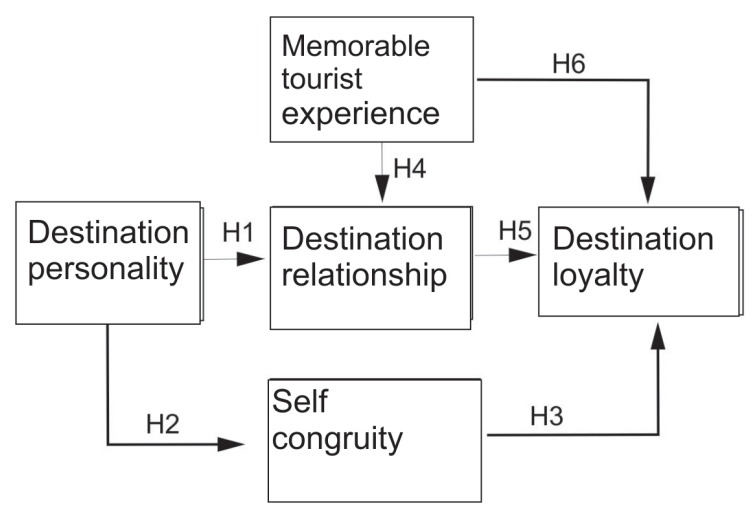

Figure 1. Empirical Research Method

\section{METHOD}

The population in this study were domestic tourists who had visited Bali Island more than two times. In this study, of the 250 respondents who received the questionnaire, there were only 184 respondents who were willing to fill out and return the questionnaire. A decent sample is between 100-200 respondents. So it can be concluded that the sample in this study is considered appropriate. The sampling technique in this study is judgment sampling, where certain conditions are needed to select samples. These conditions include the distribution of questionnaires, including the cities of Surakarta, Klaten, Sragen, Sukoharjo, Boyolali, Karanganyar, and Semarang.

In this study, there were 184 respondents. Of the 184 respondents, 75 respondents were female $(40.76 \%)$, and 109 respondents were male (59.24\%). Profile of respondents by the level of education was as follows respondents with a high school education were 32 people (17.39\%), of respondents with a bachelor degree of 144 people $(78.26 \%)$, and respondents with a master degree as much as $8(4.35 \%)$.

Destination personality is defined as several human characteristics found on specific brand (Aaker, 1997). The dimensions of destination personality which are adapted from Aa- 
ker (1997) are sincerity, gladness, competence, and discourtesy.

The memorable tourist experience is a tourism experience which is easy to be remembered although the moment happened a long time before (Sthapit, 2013). The indicators of memorable tourist experience are adapted from Brakus et al. (2009), including sensing experience, memorable feeling experience, memorable thinking experience, and memorable act experience.

Destination relationship is defined as a relationship between tourists and tourist destination. The indicators of destination relationship consist of satisfaction, trust, and engagement with tourist destination (Yuksel et al., 2010; Chen \& Phou, 2013; Lee \& Shen, 2013; Veasna et al., 2013; Loureiro, 2014).

Self-congruence is a congruity or incongruity between the perception of a destination's image with the tourist' self-image (Ahn et al., 2013). There are two dimensions of self congruence; those are actual and ideal
(Chon, 1992b; Litvin \& Goh, 2002; Litvin \& Kar, 2003; Kastenholz, 2004).

The indication of loyal tourist towards tourist destination could be seen when the tourist has the desire to revisit and telling about the tourist destination (Chi \& Qu, 2008).

All the items were measured by Likert scale 7 points $(1=$ strongly disagree, $7=$ strongly agree).

\section{RESULT AND DISCUSSION}

\section{Validity and Reliability}

Testing reliability and validity is done to test valid and reliable instruments developed (Table 1). Reliability can be seen from the composite reliability or also called construct reliability (Hair et al., 2010). Composite reliability is used because it is almost similar to Cronbach alpha (Hulland, 1999). Instruments have reliability if the composite reliability is more than 0.7(Hair et al., 2010). Composite reliability in this study is 0.799 for destination personality;

Table 1. Composite Reliability, AVE, dan Factor Loading

\begin{tabular}{lccc}
\hline Variable and Indicator & $\begin{array}{c}\text { Composite } \\
\text { Reliability }\end{array}$ & AVE & Factor Loading \\
\hline Destination Personality & 0.799 & 0.501 & \\
Sincerity (DP1) & & & 0.692 \\
Excitement (DP2) & & & 0.689 \\
Competence (DP3) & & & 0.671 \\
Ruggedness (DP4) & 0.903 & 0.700 & 0.772 \\
Memorable Tourist Experience & & & \\
Memorable Sensing Experience (MTE1) & & & 0.810 \\
Memorable Feeling Experience (MTE2) & & & 0.815 \\
Memorable Thinking Experience (MTE3) & & & 0.846 \\
Memorable Action Experience (MTE4) & 0.825 & 0.702 & 0.874 \\
Self-congruence & & & \\
1. Actual self (SC1) & & & 0.886 \\
2. Ideal Self (SC2) & 0.873 & 0.704 & 0.787 \\
Destination Relationship & & & \\
Satisfaction (DR1) & & & 0.607 \\
Trust (DR2) & & & 0.918 \\
Commitment (DR3) & 0.811 & 0.682 & 0.949 \\
Destination Loyalty & & & \\
Word Of mouth (DL1) & & 0.863 \\
Revisit (DL2) & & 0.787 \\
\hline
\end{tabular}


0.903 for the memorable tourist experience; 0.825 for self congruence; 0.873 for destination relationship; and 0.811 for destination loyalty. The validity of this study uses loading and AVE factors. An instrument that has good validity if the AVE and loading factor is more than 0.5 (Fornell \& Larcker, 1981; Hair et al., 2010). The value of AVE is 0.501 for destination personality; 0.700 for a memorable tourist experience; 0.702 for self congruence; 0.704 for destination relationship; and 0.682 for destination loyalty. All loading factor values are above the cutoff value. So it can be concluded that the instruments developed in this study are valid and reliable.

\section{Measurement Model}

The goodness of fit shows fit or non-fit of data with the proposed model (Hair et al., 2010). In this study, the measurement model indicated moderate model fit $(\mathrm{NFI}=0.834$, IFI $=$ 0.862, TLI=0.831, dan CFI $=0.861$ ).

\section{Structural Model}

The structural model illustrates the relationship between latent variables (Byrne, 2010). The structural model proposed in this study illustrates the relationship between destination personality, self congruence, memorable tourist experience, destination relationship, and destination loyalty (Table 2). In this study, six hypotheses were proposed. The six hypotheses were tested, and the results were four accepted hypotheses ( $\mathrm{H} 1, \mathrm{H} 2, \mathrm{H} 5$, and $\mathrm{H} 6)$, and the other two hypotheses were rejected ( $\mathrm{H} 3$ and $\mathrm{H} 4)$.
Destination personality can have a positive and significant effect on self congruity. The results of this study are the same as previous studies (Fournier, 1998; Chen \& Phou, 2013). Brand personality or brand relationship has the same relevance, namely the same brand-based theory that considers brands like humans. Hanby (1999) explained that brand personality and brand relationship both consider brands as living entities. Brand personality explains the human characteristics attached to the brand (Aaker, 1997), while brand relation is a relationship between consumers and brands that is analogous to relationships with humans. Brands that have human characteristics will make consumers have a close relationship with the brand (Avis \& Aitken, 2015). Tourist locations that have personalities will make consumers satisfied, trusted, and committed to the tourist sites. Satisfied trust and commitment are dimensions of brand relationship (Yuksel et al., 2010; Chen \& Phou, 2013; Lee \& Shen, 2013; Veasna et al., 2013; Loureiro, 2014). Brand personality will have an impact on the connection between brands and consumers (Park \& Jung, 2010)

In this study, destination personality has a positive and significant influence on self congruity. The results of this study are the same as previous studies (Sirgy \& Su, 2000; Usakli \& Baloglu, 2011). Self congruity is a match/ incompatibility between the perception of the destination image and the tourist's self-image (Ahn et al., 2013). One will compare his perception of the brand to be consumed. The personality of a Bali tourist destination makes tourists

Table 2. Hypothesis Testing

\begin{tabular}{lll}
\hline Hypothesis & Result & \\
\hline H1: Destination Personality $\rightarrow$ Destination Relationship & $2.676^{* *}$ & H1 accepted \\
H2: Destination Personality $\rightarrow$ Self Congruence & $1.023^{* *}$ & H2 accepted \\
H3: Self-congruence $\rightarrow$ destination loyalty & -3.035 & H3 rejected \\
H4: Memorable Tourist Experience $\rightarrow$ Destination Relationship & -1.572 & H4 rejected \\
H5: Destination Relationship $\rightarrow$ Destination Loyalty & $1.133^{*}$ & H5 accepted \\
H6: Memorable Tourist Experience $\rightarrow$ Destination Loyalty & $2.827^{* *}$ & H6 accepted \\
\hline $\begin{array}{ll}* \operatorname{sign}<0,05 \\
\text { sign }<0,01\end{array}$ & &
\end{tabular}


see themselves fit or not with the personality of a Bali tourist destination.

Self-Congruity has a negative but not significant effect on Destination Loyalty. The results of this study are different from previous studies where self congruity can significantly increase brand loyalty (Han \& Back, 2008; Liu et al., 2012a; Kang et al., 2015). Self congruity is the relationship between self-concept, and the symbolic value of the brand purchased will affect tourist behavior (Chon, 1992b). In this stu$\mathrm{dy}$, there was no positive influence between self congruity and tourist behavior, especially destination loyalty. The reason why self congruity is not able to have a positive and significant effect on brand loyalty is that it is possible for tourist destinations on the island of Bali to be a tourist destination that is considered a luxury brand for domestic tourists. Brand personality congruity is not able to increase brand loyalty, especially in luxury brands (Liu et al., 2012b).

This study shows that the memorable tourist experience has a negative and insignificant effect on the destination relationship. The higher the memorable tourist experience, the relationship between consumers and brands will be increasingly tight. the results of this study do not support the results of previous studies (Fournier, 1998), where a memorable experience can significantly increase brand relationship. Although memorable tourist experience had a negative effect on brand relationships, the memorable tourist experience was able to increase brand loyalty. This means that tourists who have a deep impression on the location of a tourist destination will have an impact on their loyalty to that destination. Tourists will come back or recommend these tourist destinations to others. The results in this study, which state that the memorable tourist experience has a positive and significant effect on brand loyalty, are similar to previous studies (Brakus et al., 2009; Biedenbach \& Marrel, 2010; Ismail et al., 2011; Sahin et al., 2011; Sathish \& Venkatesakumar, 2011).

The brand relationship in this study can influence loyalty positively and significantly. The results of this study confirm the previous studies (Kressmann et al., 2006; Hollebeek, 2011). The concept of the brand relationship in this study concerns the relationship between tourists and tourist destinations. Tourist relations are indicated by satisfaction, trust, and commitment. Consumers who are satisfied, believe, and committed to a brand will be able to influence their loyalty to tourist destinations, especially Bali.

\section{CONCLUSION AND RECOMMENDATION}

There are six hypotheses built in this study. After being tested, only four hypotheses were accepted, namely: Destination personality has a positive and significant effect on destination relationship, Destination personality has a positive and significant effect on self congruence, Destination relationship has a positive impact on destination loyalty, and the Memorable tourist experience has a positive and significant effect on destination loyalty. There are two hypotheses that are not accepted, among others: Self-congruence has a negative effect on destination loyalty, the Memorable tourist experience has a negative effect on the destination relationship.

The theoretical implications in this study are related to the concept of the memorable tourist experience. In this study, the memorable tourist experience can increase loyalty but not be able to increase destination relationship. Memory is an important part of the concept of a memorable tourist experience. Memory is divided into episodic and semantic memory (Tulving, 1979). Episodic memory, otherwise known as autobiographical memory, is the memory of tourists who relate to their tourism experience while semantic memory is related to tourist knowledge about tourist destinations. The memory is more likely to make tourists make decisions in the future rather than thinking about the relationship between the brand and themselves. The decision in question is a decision to revisit intention or loyal to a tourist destination (Kim et al., 2012a; Kim et al., 2012b). Experience (memory autobiography) and tourist 
knowledge (semantic memory) will be able to increase destination loyalty compared to destination relationships.

The managerial implications in this study are (1) There are several drivers of loyalty in tourist destinations, namely the memorable tourist experience and brand relationship. The government must be able to build experience design for tourist destinations in Bali. Experience design can be in the form of physical context and relation context. Physical contact that is built is a tourist destination in Bali must look clean and neat, the development carried out does not damage the authenticity of nature and culture, and the building is adapted to the theme of the local culture of the Balinese population. Tourists come to Bali because they want to see and feel the beauty and authenticity of nature along with its culture. The relation context that must be built is to build trust and politeness towards tourists. (2) The government must highlight the brand personality of Bali. One way is to make a slogan or tagline about Bali. The personality that is easily understood by tourists will make tourists easily compare themselves (self congruity) with the personality of tourist destinations

The weaknesses in this study are (1) the goodness of fit indicator is still of average value; (2) the study is still limited to respondents of local tourists. Future research is expected (1) research respondents are local and foreign tourists. What is suggested is to compare the results of the study when using respondents from local and foreign tourists. (2) To anticipate the average goodness of fit, then use the SEM-PLS analysis approach.

\section{Acknowledgments}

We thank to Ristekdikti for funding this research. This research was funded through the "Hibah Penelitian Dosen Pemula" scheme in 2016.

\section{REFERENCES}

Aaker, D. (1996). Building Strong Brands. New York: The Free Press.
Aaker, J. L. (1997). Dimensions of Brand Personality. Journal of Marketing Research, 34(3), 347356.

Abubakirova, A., Syzdykova, A., Kelesbayev, D., Dandayeva, B., \& Ermankulova, R. (2016). Place of Tourism in the Economy of Kazakhstan Republic. Procedia Economics and Finance, 39, 3-6.

Ahn, T., Ekinci, Y., \& Li, G. (2013). Self-Congruence, Functional Congruence, and Destination Choice. Journal of Business Research, 66, 719-723.

Al-Ansi, A., \& Han, H. (2019). Role of HalalFriendly Destination Performances, Value, Satisfaction, and Trust in Generating Destination Image and Loyalty. Journal of Destination Marketing \& Management, 13(2), 51-60.

Alegre, J., \& Juaneda, C. (2006). Destination Loyalty: Consumers' Economic Behavior. Annals of Tourism Research, 33(3), 684-706.

Almeida-Santana, A., \& Moreno-Gil, S. (2018). Understanding Tourism Loyalty: Horizontal Vs. Destination Loyalty. Tourism Management, 65(April), 245-255.

Alrawadieh, Z., Alrawadieh, Z., \& Kozak, M. (2019). Exploring the Impact of Tourist Harassment on Destination Image, Tourist Expenditure, and Destination Loyalty. Tourism Management, August(13-20).

Ardyan, E., \& Susanti, A. (2018). The Effect of City Brand Love on Tourist Based City Brand Equity: City Branding Study in Indonesia. International Journal of Asian Business and Information Management, 9(3), 44-60.

Avis, M., \& Aitken, R. (2015). Intertwined: Brand Personification, Brand Personality and Brand Relationships in Historical Perspective. Journal of Historical Research in Marketing, 7(2), 208-231.

Batra, R., Ahuvia, A., \& Bagozzi, R. P. (2012). Brand Love. Journal of Marketing, 76, 1-16.

Beerli, A., Meneses, G. D., \& Gil, S. M. (2007). SelfConqruity and Destination Choice. Annals of Tourism Research, 34(3), 571-587.

Biedenbach, G., \& Marrel, A. (2010). The Impact of Customer Experience on Brand Equity in a Business to Business Service Setting. Journal of Brand Management, 17(6), 446-458.

Boksberger, P., Dolnicar, S., Laesser, C., \& Randle, M. (2011). Self-Congruity Theory: to What 
Extent Does it Hold in Tourism. Journal of Travel Research, 50(4), 454-464.

Brakus, J. J., Schmitt, B. H., \& Zarantonello, L. (2009). Brand Experience: What Is It? How Is it Measured? Does it Affect Loyalty? Journal of Marketing, 73, 52-68.

Byrne, B. M. (2010). Structural Equation Modeling with Amos. New York: Routledge.

Caprara, G. V., Barbaranelli, C., \& Guido, G. (2001). Brand Personality: How to Make the Metaphor Fit?. Journal Of Economic Psychology, 22, 377-395.

Chen, C.-F., \& Chen, F.-S. (2010). Experience Quality, Perceived Value, Satisfaction and Behavioral Intentions for Heritage Tourists. Tourism Management, 31(1), 29-35.

Chen, C.-F., \& Phou, S. (2013). A Closer Look At Destination: Image, Personality, Relationship, and Loyalty. Tourism Management, 36, 269-278.

Chi, C. G.-Q. \& Qu, H. (2008). Examining the Structural Relationships of Destination Image, Tourist Satisfaction, and Destination Loyalty: an Integrated Approach. Tourism Management, 29, 624-636.

Chon, K.-S. (1992a). Self Image/Destination Image Congruity. Annals of Tourism Research, 19(2), 360-363.

Chon, K. S. (1992b). Self-Image/Destination Image Congruity. Annals of Tourism Research, 19, 360-363.

Cohen, E. (1979). A Phenomenology Tourism Experience. Sociology, 13, 179-201.

Cole, S. (2012). A Political Ecology of Water Equity and Tourism: a Case Study From Bali. Annals of Tourism Research, 39(2), 12211241.

Cooper, C., Fletcher, J., Gilbert, D., \& Wanhill, S. (1993). Tourism Principles \& Practice. USA: Pitman Publishing.

Cossio-Silva, F.-J., Revilla-Camacho, M.-A., \& VegaVasquez, M. (2019). The Tourist Loyalty Index: a New Indicator for Measuring Tourist Destination Loyalty?. Journal Of Innovation \& Knowledge, 4(2), 71-77.

Elmeida-Santana, A., \& Moreno-Gil, S. (2017). New Trends in Information Search and Their Influence on Destination Loyalty: Digital Destinations and Relationship Marketing. Journal of Destination Marketing \& Management, 6, 150-161.
Enright, M. J., \& Newton, J. (2004). Tourism Destination Competitiveness: a Quantitative Approach. Tourism Management, 25(6), 777788.

Fornell, C., \& Larcker, D. F. (1981). Evaluating Structural Equation Models With Unobservable Variables and Measurement Error. Journal of Marketing Research, 18(1), 39-50.

Fournier, S. (1998). Consumers and their Brands: Developing Relationship Theory in Consumer Research. Journal of Consumer Research, 24(March), 343-373.

Fu, X. (2019). Existential Authenticity and Destination Loyalty: Evidence from Heritage Tourists. Journal of Destination Marketing \& Management, 12, 84-94.

Gibbons, J. D., \& Fish, M. (1989). Indonesia's International Tourism: a Shifting Industry in Bali. International Journal of Hospitality Management, 8(1), 63-70.

Gursoy, D., Chen, J. S., \& Chi, C. G. (2014). Theoretical Examination of Destination Loyalty Formation. International Journal of Contemporary Hospitality Management, 26(5), 809-827.

Ha, S., \& Im, H. (2012). Identifying the Role of SelfCongruence on Shopping Behavior in the Context of U.S. Shopping Malls. Cloting and Textiles Research Journal, 30(2), 87-101.

Hair, J. F., Black, W. C., Babin, B. J., \& Anderson, R. E. (2010). Multivariate Data Analysis (7 Ed.). New York: a Global Perspective.

Han, H., \& Back, K.-J. (2008). Relationships among Image Congruencem Consumption Emotions, and Customer Loyalty in the Lodging Industry. Journal of Hospitality \& Tourism Research, 32(4), 467-490.

Hanby, T. (1999). Brands: Dead or Alive? Journal of the Market Research Society, 14(5), 649-656.

Health, A. P., \& Scott, D. (1998). The Self-Concept and Image Congruence Hypothesis: an Empirical Investigation in the Motor Vehicle Market. European Journal of Marketing, 32(11/12), 1110-1123.

Holbrook, M. B., \& Hirschman, E. C. (1982). The Experiential Aspects of Consumption: Consumer Fantasies, Feeling, and Fun. Journal of Consumer Research, 9(2), 132-140.

Hollebeek, L. D. (2011). Demystifying Customer Brand Engagement: Exploring the Loyalty Nexus. Journal of Marketing Management, 27(7/8), 785-807. 
Elia Ardyan \& Utomo Wibisono/ Between Self Congruity, Destination Relationship and Memorable Tourist

Hosany, S., Elkinci, Y., \& Uysal, M. (2006). Destination Image and Destination Personality: an Application of Branding Theories to Tourism Place. Journal of Business Research, 59, 638642.

Hosany, S., \& Martin, D. (2012). Self-Image Congruence in Consumer Behavior. Journal of Business Research, 65, 685-691.

Hulland, J. (1999). Use of Partial Least Squares (PLS) on Strategic Management Research: a Review of Four Recent Studies. Strategic Management Journal, 20, 195-204.

Ismail, A. R., Melewar, T. C., Lim, L., \& Woodside, A. (2011). Customer Experiences with Brands: Literature Review and Research Directions. Marketing Review, 11(3), 205-225.

Jani, D., \& Han, H. (2012). Testing the Moderation Effect of Hotel Ambience on the Relationships among Social Comparison, Affect, Satisfaction, and Behavioral Intentions. Journal of Travel \& Tourism Marketing, 31(6), 731746.

Johar, J. S., \& Sirgy, M. J. (1989). Positioning Models in Marketing: toward a Normative-Integrated Model. Journal of Business \& Psychology, 3, 437-485.

Kang, J., Tang, L., \& Lee, J. Y. (2015). Self Congruity and Functional Congruity in Brand Loyalty. Journal of Hospitality \& Tourism Research, 39(1), 105-131.

Kastenholz, E. (2004). Asses Sment and Role of Destination-Sel F-Congruity. Annual Tourism Research, 31(3), 719-723.

Kim, J.-H., Ritchie, J. R. B., \& Mccormick, B. (2012a). Development of a Scale to Measure Memorable Tourism Experiences. Journal of Travel Research, 51(1), 12-25.

Kim, K., Hallab, Z., \& Kim, J.-H. (2012b). The Moderating Effect of Travel Experience in a Destination on the Relationship Between the Destination Image and the Intention to Revisit. Journal of Hospitality Marketing \& Management, 21, 486-505.

Klipfel, J. A., Barclay, A. C., \& Borckorny, K. M. (2014). Self-Congruity: a Determinant of Brand Personality. Journal of Marketing Development and Competitiveness, 8(3), 130-143.

Kotler, P., \& Keller, K. L. (2012). Marketing Management. New Jersey: Pearson Education, Inc.

Kressmann, F., Sirgy, M. J., Herrmann, A., Huber, F., Huber, S., \& Lee, D.-J. (2006). Direct and
Indirect Effects of Self-Image Congruence on Brand Loyalty. Journal of Business Research, 59, 955-964.

Kumar, R., Luthra, A., \& Datta, G. (2006). Linkages between Brand Personality and Brand Loyalty: a Qualitative Study in an Emerging Market in the Indian Context. South Asian Journal of Management, 13(2), 11-35.

Kwak, D. H., \& Kang, J.-H. (2009). Symbolic Purchase in Sport: the Roles of Self-Image Congruence and Perceived Quality. Management Decision, 47(1), 85-99.

Law, A., De Lacy, T., Lipman, G., \& Jiang, M. (2016). Transitioning to a Green Economy: the Case of Tourism in Bali, Indonesia. Journal of Cleaner Production, 111, 295-305.

Lee, T. H., \& Shen, Y. L. (2013). The Influence of Leisure Involvement and Place Attachment on Destination Loyalty: Evidence from Recreationists Walking Their Dogs in Urban Parks. Journal of Environment Psychology, 33, 76-85.

Li, K. X., Jin, M., \& Shi, W. (2018). Tourism as an Important Impetus to Promoting Economic Growth: a Critical Review. Tourism Management Perspectives, 26(April), 135-142.

Litvin, S., \& Goh, H. (2002). Self-Image Congrue Nce: a Valid Tourism Theory?. Tourism Management, 23, 81-83.

Litvin, S. W., \& Kar, G. H. (2003). Individualism/ Collectivism as a Moderating Factor to the Self-Image Congruity Concept. Journal of Vacation Marketing, 10(1), 23-42.

Liu, C.-R., Lin, W.-R., \& Wang, Y.-C. (2012a). Relationship between Self-Congruity and Destination Loyalty: Differences between First-Time and Repeat Visitors. Journal of Destination Marketing \& Management, 1, 118-123.

Liu, F., Li, J., Mizarski, D., \& Soh, H. (2012b). SelfCongruity, Brand Attitude, and Brand Loyalty: a Study on Luxury Brands. European Journal of Marketing, 46(7/8), 922-937.

Loureiro, S. M. C. (2014). The Role of Rural Tourism Experience Economy in Place Attachment and Behavioral Intentions. International Journal of Hospitality Management, 40, 1-9.

Mariani, M. M., \& Baggio, R. (2012). Special Issue: Managing Tourism in a Changing World: Issues and Cases. Anatolia: an International Journal of Tourism and Hospitality, 23(1), 1-3. 
Mctaggart, W. D. (1980). Tourism and Tradition in Bali. World Development, 8, 457-466.

Meleddu, M., Paci, R., \& Pulina, M. (2015). Repeat Behavior and Destination Loyalty. Tourism Management, 50, 159-171.

Mill, R., \& Morrison, A. (2009). The Tourism System (Sixth Ed.). USA: Kendall Hunt.

Morgan, N. A., \& Pritchard, A. (2010). Meeting the Destination Branding Challenge. in N. A. Morgan, A. Pritchard \& R. Pride (Eds.), Destination Branding: Creating the Unique Destination Proposition (Pp. 59-77). ButterworthHeinemann: Oxford.

Murphy, L., Moscardo, G., \& Benckendorff, P. (2007). Using Brand Personality to Differentiate Regional Tourism Destinations. Journal of Travel Research, 41, 5-14.

Oliver, R. L. (1999). Whence Consumer Loyalty? Journal of Marketing, 63((Special Issue)), 3334.

Oppermann, M. (2000). Tourism Destination Loyalty. Journal of Travel Research, 39(1), 78-84.

Park, C. W., Jaworski, B. J., \& Maclnis, D. J. (1986). Strategic Brand Concept-Image Management. Journal of Marketing, 50(4), 135-145.

Park, H. H., \& Jung, G. O. (2010). A Study on the Impact of the Congruence of Store Personality and Self-Image toward Relationship Strength and Store Loyalty. Journal of Marketing Studies, 16, 45-68.

Park, S.-Y., \& Lee, E. M. (2005). Congruence between Brand Personality and Self-Image, and the Mediating Roles of Satisfaction and Consumer-Brand Relationship on Brand Loyalty. in Y.-U. Ha \& Y. Yi (Eds.), Asia Pacific Advances in Consumer Research (Vol. 6). Duluth, Mn: Association for Consumer Research.

Pawle, J., \& Cooper, P. (2006). Measuring EmotionLovemarks, the Future Beyond Brands. Journal of Advertising, 46(1), 38-48.

Pearce, D. G., \& Schanzel, H. A. (2013). Destination Management: the Tourists' Perspective. Journal of Destination Marketing \& Management, 2, 137-145.

Pine, B. J., \& Gilmore, J. H. (1998). Welcome to the Experience Economy. Havard Business Review(July-August), 97-105.

Pizam, A. (2010). Creating Memorable Experiences. International Journal of Hospitality Management, 29, 343.
Plummer, J. T. (1985). How Personality Make a Difference?. Journal of Advertising Research, 24(6), 27-31.

Plummer, J. T. (2000). How Personality Makes a Difference. Journal of Advertising Research, 40(06), 79-84.

Ponsonby-Mccabe, S., \& Boyle, E. (2006). Understanding Brands as Experiential Spaces: Axiological Implications for Marketing Strategists. Journal of Strategic Marketing, 14(2), 175-189.

Prahalad, C. K., \& Ramaswamy, V. (2004). Co-Creation Experiences: the Next Practice in Value Creation. Journal of Interactive Marketing, 18(3), 5-14.

Rageh, A., Melewar, T. C., \& Woodside, A. (2013). Using Netnography Research Method to Reveal the Underlying Dimentions of the Customer/Tourist Experience. Qualitative Market Research: an International Journal, 16(2), 126-149.

Sahin, A., Zehir, C., \& Kitapci, H. (2011). The Effects of Brand Experiences, Trust and Satisfaction on Building Brand Loyalty, an Empirical Research on Global Brands. Procedia-Social and Behavioral Sciences, 24, 1288-1301.

Sathish, A. S., \& Venkatesakumar, R. (2011). Coffee Experience and Driver of Satisfaction, Loyalty in a Coffe Outlet With Special Reference to Cafe Coffe Day. Journal of Temporary Management Research, 5(2), 1-13.

Schmitt, B. H. (1999a). Experiential Marketing. Journal of Marketing Management, 15, 53-67.

Schmitt, B. H. (1999b). Experiential Marketing: How to Get Customers to Sense, Feel, Think, Act, and Relate to Your Company and Brand. New York: The Free Press.

Sirgy, M. J., \& Su, C. (2000). Destination Image, Self-Congruity, and Travel Behavior: Toward an Integrative Model. Journal of Travel Research, 38(4), 340-352.

Sthapit, E. (2013). Tourists' Perception of Memorable Experience: Testing the Memorable Experience Scale (Mtes) among Tourists to Rovaniemi, Lapland. Lapland.

Sudiarta, I. N., \& Suardana, I. W. (2016). Tourism Destination Planning Strategy: Analysis and Implementation of Marketing City Tour in Bali. Procedia-Social and Behavioral Sciences, 227, 664-670. 
Elia Ardyan \& Utomo Wibisono/ Between Self Congruity, Destination Relationship and Memorable Tourist

Sun, X., Chi, C. G.-Q., \& Xu, H. (2013). Developing Destination Loyalty: the Case of Hainan Island. Annals of Tourism Research, 43, 547577.

Sutawa, G. K. (2012). Issues on Bali Tourism Development and Community Empowerment to Support Sustainable Tourism Development. Procedia Economics and Finance, 4, 413-422.

Swann, W. B., Stein-Setoussi, A., \& Giesler, R. B. (1992). Why People Self-Verify. Journal of Personality and Social Psychology, 62(3), 392401.

Tasci, A. D. A. (2017). A Quest for Destination Loyalty by Profiling Loyal Travelers. Journal of Destination Marketing \& Management, 6(3), 207-220.

Tho, N. D., Trang, N. T. M., \& Olsen, S. O. (2016). Brand Personality Appeal, Brand Relationship Quality and Wom Transmission: a Study of Consumer Markets in Vietnam. Asia Pacific Business Review, 22(2), 307-324.

Tulving, E. (1979). Relation between Encoding Specificity and Levels of Precessing. in F. I. M. Craik \& L. Cermak (Eds.), Levels of Processing in Human Memory. Hillsdale, Nj: Erlbaum.

Tung, V. W. S., \& Ritchie, J. R. B. (2011). Exploring the Essense of Memorable Tourism Experiences. Annals of Tourism Research, 38(4), 1367-1386.
Usakli, A., \& Baloglu, S. (2011). Brand Personality of Tourist Destination: an Application of Self-Congruity Theory. Tourism Management, 32, 114-127.

Veasna, S., Wu, W.-Y., \& Huang, C.-H. (2013). The Impact of Destination Source Credibility on Destination Satisfaction: the Mediating Effects of Destination Attachment and Destination Image. Tourism Management, 36, 511-526.

Veloutsou, C. (2015). Brand Evaluation, Satisfaction and Trust as Predictors of Brand Loyalty: the Mediator-Moderator Effect of Brand Relationships. Journal of Consumer Marketing, 32(6), 405-421.

Walls, A. R., Okumus, F., Wang, Y.-C., \& Kwun, D. J.-W. (2011). Understanding the Customer Experience : an Exploratory Study of Luxury Hotels. Journal of Hospitality Marketing \& Management, 20(2), 166-197.

Wang, N. (2002). The Tourist as Peak Consumer. in G. M. S. Dann (Ed.), The Tourist as a Metaphor of The Social World. Wallingford, Oxon: Cabi Publishing.

William, A. (2006). Tourism and Hospitality Marketing: Fantasy, Felling and Fun. International Journal of Contemporary Hospitality Management, 18(6), 482-495.

Yuksel, A., Yuksel, F., \& Bilim, Y. (2010). Destination Attachment: Effects on Customer Satisfaction and Cognitive, Affective and Conative Loyalty. Tourism Management, 31, 274-284. 